Environmental Compliance Department

\title{
POLLUTION PREVENTION \\ PROGRAM IMPLEMENTATION \\ PLAN
}

In case of termination or transfer, return this manual to Document Control, K3-70.

\section{RECEIVED \\ DEC 301997 \\ OSTI}

Prepared by:

Textetersu Jor JAErigel

Approved for Use and Application by:

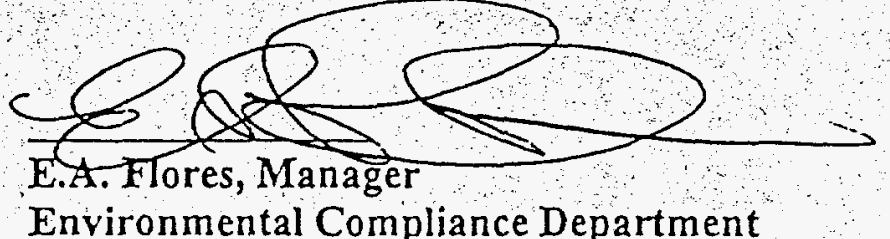

Environmental Compliance Department

Pacific Northwest National Laboratory

Richland, Washington 99352

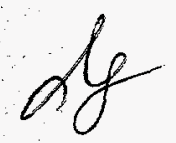

ESTRIBU MONON OF NIS DOCUMENT IS UNLMITES 


\section{DISCLAIMER}

Portions of this document may be illegible electronic image products. Images are produced from the best available original document. 


\section{Contents}

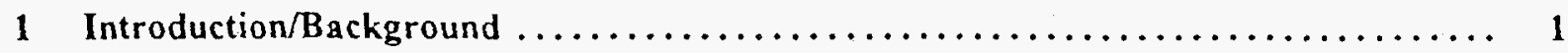

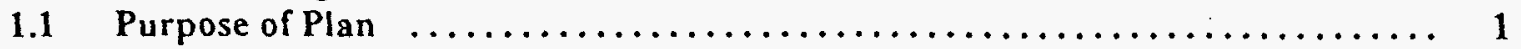

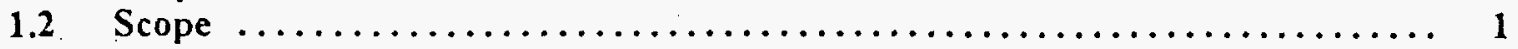

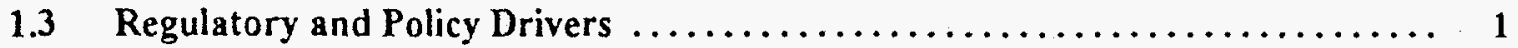

2 Policy, Objectives, Implementation Strategy, Goals, and Performance Measures ..... 2

2.1 Program Policy ..................................... 2

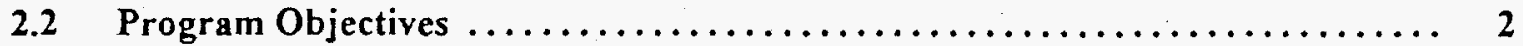

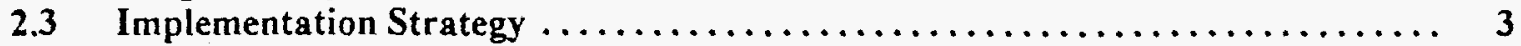

2.4 Goals and Performance Measures $\ldots \ldots \ldots \ldots \ldots \ldots \ldots \ldots \ldots \ldots \ldots \ldots \ldots, \ldots \ldots \ldots$

3 Organization Structure and Resources $\ldots \ldots \ldots \ldots \ldots \ldots \ldots \ldots \ldots \ldots \ldots \ldots \ldots \ldots$

3.1 Relationship to Hanford Site Plan/Other Site Contractors .............. 4

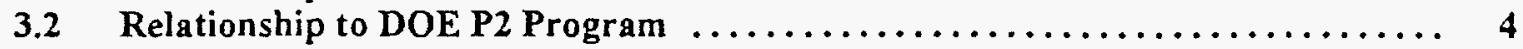

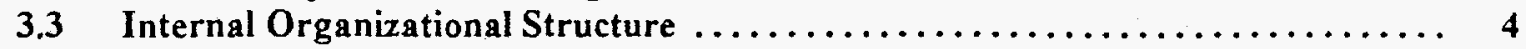

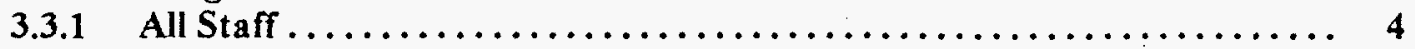

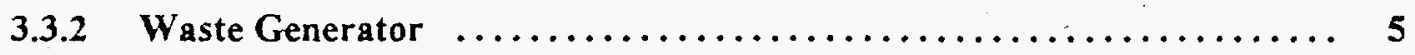

3.3.3 Environmental Compliance Department $\ldots \ldots \ldots \ldots \ldots \ldots \ldots \ldots \ldots \ldots \ldots$

3.3.4 Waste Management Services Department $\ldots \ldots \ldots \ldots \ldots \ldots \ldots \ldots \ldots$

3.3.5 Environmental Technology Division P2 Product Line ............ 6

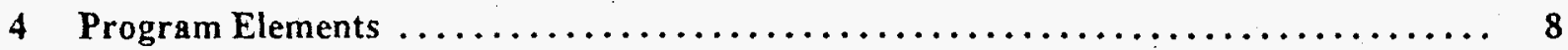

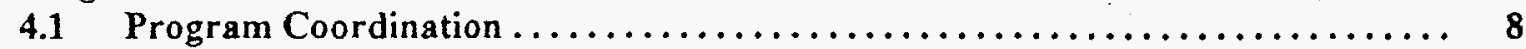

4.1.1 Program Planning $\ldots \ldots \ldots \ldots \ldots \ldots \ldots \ldots \ldots \ldots \ldots \ldots \ldots \ldots \ldots \ldots \ldots$

4.1.2 Pollution Prevention Opportunity Assessments $\ldots \ldots \ldots \ldots \ldots \ldots \ldots \ldots$. 8

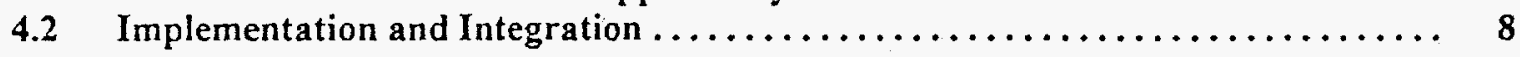

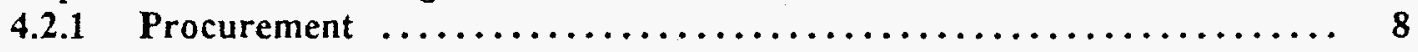

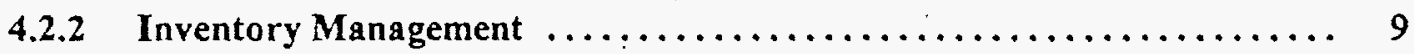

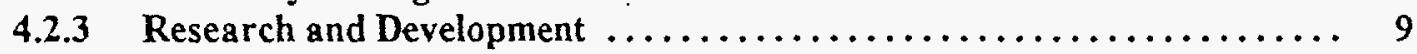

4.2.4 Resource Conservation ............................. 9

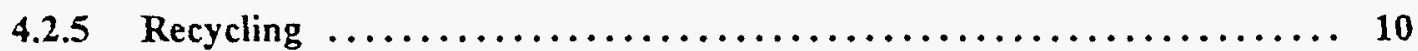

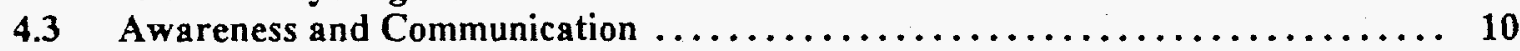

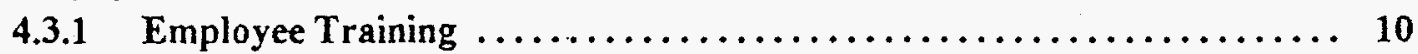

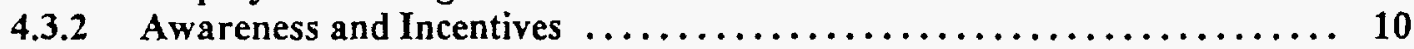

4.3.3 External Outreach ................................. 11

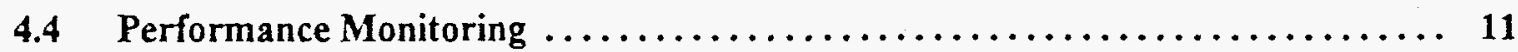

4.4.1 Material Inventory Tracking $\ldots \ldots \ldots \ldots \ldots \ldots \ldots \ldots \ldots \ldots \ldots \ldots \ldots$

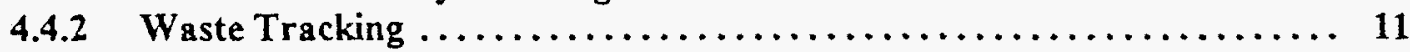

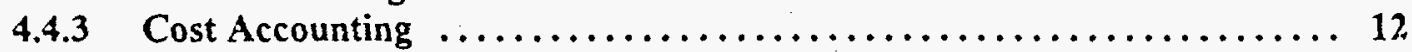

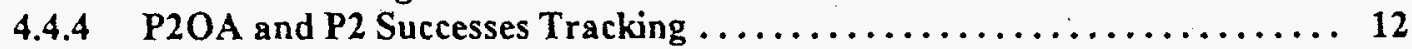

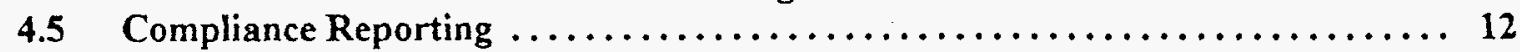

4.5.1 Emergency Planning and Community Right-to-Know Act 311/312/313

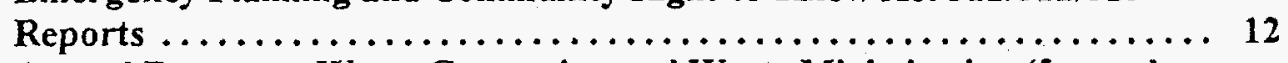

4.5.2 Annual Report on Waste Generation and Waste Minimization (formerly

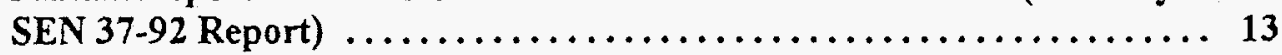

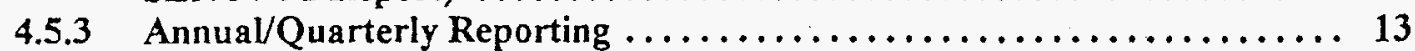

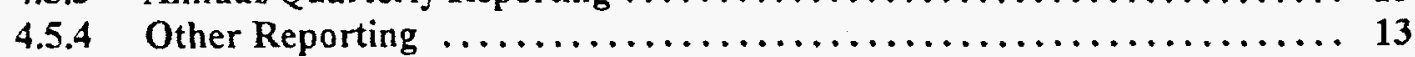

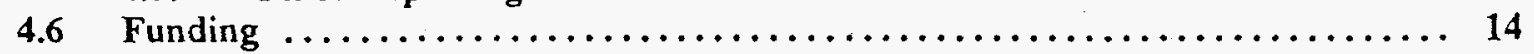

Appendix 1, Glossary $\quad \ldots \ldots \ldots \ldots \ldots \ldots \ldots \ldots \ldots \ldots \ldots \ldots \ldots \ldots \ldots \ldots \ldots \ldots \ldots$

Appendix 2, Applicable Pollution Prevention Regulations and Policies ........... 17 


\subsection{Purpose of Plan}

The Pollution Prevention Program Implementation Plan (the Plan) describes the Pacific Northwest National Laboratory's (PNNL) Pollution Prevention (P2) Program. The Plan also shows how the P2 Program at PNNL will be in support of and in compliance with the Hanford Site Waste Minimization and Pollution Prevention (WMin/P2) Awareness Program Plan (DOE-RL, 1996) and the Hanford Site Guide for Preparing and Maintaining Generator Group Pollution Prevention Program Documentation (DOE-RL, 1995). In addition, this plan describes how PNNL will demonstrate compliance with various legal and policy requirements for $\mathrm{P} 2$.

This Plan will be reviewed annually and updated at least every three years to reflect changes in regulatory and DOE requirements, program elements, implementation schedules, and/or new initiatives.

\subsection{Scope}

This plan documents the strategy for implementing the PNNL P2 Program. The scope of the P2 Program includes implementing and helping to implement P2 activities at PNNL. These activities will be implemented according to the Environmental Protection Agency's (EPA) hierarchy of source reduction, recycling, treatment, and disposal.

The PNNL P2 Program covers all wastes generated at the Laboratory. These include hazardous waste, low-level radioactive waste, radioactive mixed waste, radioactive liquid waste system waste, polychlorinated biphenyl waste, transuranic waste, and sanitary waste generated by activities at PNNL.

Materials, resource, and energy conservation are also within the scope of the PNNL P2 Program.

\subsection{Regulatory and Policy Drivers}

The regulatory and policy requirements for the PNNL P2 Program include the laws, policies, regulations, Executive Orders, U.S. Department of Energy (DOE) Orders listed in Appendix 2, and policies identified in the Hanford Site WMin/P2 Awareness Plan.

\section{DISCLAIMER}

This report was prepared as an account of work sponsored by an agency of the United States This report was prepared as an account of work sponsored by an agency of the United States employees, makes any warranty, express or implied, or assumes any legal liability or responsibility for the accuracy, completeness, or usefulness of any information, apparatus, product, or process disclosed, or represents that its use would not infringe privately owned rights. Reference herein to any specific commercial product, process, or service by trade name, trademark, manufacturer, or otherwise does not necessarily constitute or imply its endorsement, recommendation, or favoring by the United States Government or any agency thereof. The views and opinions of authors expressed herein do not necessarily state or reflect those of the United States Government or any agency thereof. 
2 Policy, Objectives, Implementation Strategy, Goals, and Performance Measures

\subsection{Program Policy}

PNNL is committed to operating in an environmentally sustainable manner that promotes efficient use of natural resources, zero waste generation at the source, and the recycle and reuse of materials to the greatest extent that is economically practical through the full participation of all PNNL staff.

\subsection{Program Objectives}

The PNNL P2 Program has established several objectives to carry out the PNNL P2 Policy. These objectives are based on the Site Plan (DOE-RL, 1996), the DOE Crosscut Plan (DOE, 1994), the DOE HQ 1996 Pollution Prevention Program Plan (DOE, 1996), other DOE guidance, and regulatory drivers. The objectives are

- reduce the volume and toxicity of waste produced by research, development, and facility support activities to as low as reasonably achievable

- raise the consciousness of Laboratory staff members so they perform their job functions in such a manner as to minimize waste generation and prevent adverse environmental impact

- promote the use of nonhazardous materials in PNNL activities to minimize the potential risks to human health and the environment

- emphasize the need for managers and staff members to plan, design, and implement measures within each work activity

- comply with federal and state regulations and DOE requirements for waste reduction and $\mathrm{P} 2$

- gather data on all types of waste generation and environmental releases and establish a baseline of this data

- promote P2 incentives, training, and awareness

- further develop generator P2 programs to enhance current P2 efforts and accomplishments at the generator level

- provide guidance to PNNL generators concerning Site Plan documentation requirements

- perform pollution prevention opportunity assessments (P2OAs) and seek additional P2OA preparation and implementation funding

- disseminate P2 information through onsite and offsite meetings, seminars, workshops, and bulletin boards

- promote internal chemical exchange and participate in site-wide chemical exchange efforts

- promote recycling and participate in site-wide recycling efforts

- commercialize and disseminate new technologies that support P2 principles and, where possible, implement these technologies within PNNL

- bring Laboratory P2 capabilities together to bear on specific internal P2 opportunities

- provide P2 Program support to other organizations outside PNNL. 


\subsection{Implementation Strategy}

PNNL can broadly be considered as having two functional areas: research functions and operational support functions. As a result, the PNNL P2 Program strategy is essentially two-fold in nature with the integration of $\mathrm{P} 2$ into both functions being coordinated by the Environmental Compliance (EC) Department. The tracking of waste generation and the coordination of materials exchange and recycling is performed by the Waste Management Services (WMS) Department. The expertise of research and development is combined with the operational support services provided by EC and WMS and applied at the generator level through the liaison activities of EC Representatives (ECRs). P2 innovations developed at PNNL are transferred to other sites and private industry from the Environmental Technologies Division (ETD) through the P2 Product Line. This constitutes the development and transmission of ideas both at PNNL and external to the Laboratory.

\subsection{Goals and Performance Measures}

The PNNL P2 Program goals have been established by EC in accordance with Executive Orders, DOE guidance, and the DOE 1996 Pollution Prevention Program Plan. PNNL's P2 goals are to support the achievement of the DOE Departmental Goals. The Departmental Goals are to be achieved by December 31,1999 , and are given below. The baseline is calendar year 1993.

\section{For Routine Operations}

- Reduce by $50 \%$ the generation of radioactive waste.

- Reduce by $50 \%$ the generation of low-level mixed waste.

- Reduce by $50 \%$ the generation of hazardous waste.

- Reduce by $33 \%$ the generation of sanitary waste.

- Reduce by $50 \%$ total releases and off-site transfers for treatment and disposal of toxic chemicals.

\section{For All Operations, Including Cleanup/Stabilization Activities}

- Recycle $33 \%$ of sanitary waste.

\section{For Affirmative Procurement}

- Increase procurement of EPA-designated recycled products to $100 \%$, except where they are not commercially available competitively at a reasonable or do not meet performance standards.

At PNNL, annual P2 goals are established in January. Both forecast and annual goals are reported to DOE Richland Operations (RL) to meet the commitment in the Site Plan of finalizing site goals by January 31 of each year. Additionally, EC establishes P2 performance indicators on a fiscal year basis. Successful meeting of these performance indicators contribute in the contract award fee for the Laboratory. 


\subsection{Relationship to Hanford Site Plan/Other Site Contractors}

PNNL is working to emphasize P2 at the generator level by encouraging incorporation of P2 Program elements at individual labs, buildings, and projects. PNNL will also strive to cooperate with other site contractors by sharing and exchanging P2 ideas, initiatives, and information to achieve the outlined goals. Part of this cooperation will include participation in monthly site-wide P2 meetings, monthly meetings with DOE-RL, participating on sitewide P2OA teams, and leading/participating on multi-contractor Hanford site projects.

\subsection{Relationship to DOE P2 Program}

PNNL will participate in the DOE complex-wide P2 Program and in Energy Research Laboratories $\mathrm{P} 2$ programs. This includes attending, presenting at, and helping organize conferences and workshops, as well as leading/participating in DOE complex-wide initiatives. PNNL will also communicate DOE requirements to all applicable PNNL employees.

\subsection{Internal Organizational Structure}

Documentation of the PNNL P2 Program is kept on a central level to facilitate communication and ensure compliance. This establishes PNNL as a single reporting generator group, as defined in DOE-RL guidance documents (DOE-RL, 1995). To date the program strategy is for the central group to focus more on finding opportunities for P2 within the Laboratory and the waste generators to implement these opportunities.

The organizations that have a role in the PNNL P2 Program Plan are listed with their responsibilities described below.

\subsubsection{All Staff}

All PNNL staff have the following responsibilities:

- Comply with all applicable environmental requirements.

- Integrate environmental considerations into their daily work.

- Seek out and practice P2 and resource conservation.

- Seek to minimize the generation of waste at the source. This includes using electronic messages, turning off lights and equipment when not in use, printing/photocopying only when necessary, car pooling, using ceramic coffee mugs, and taking any other actions to prevent waste and conserve resources.

- Recycle their office waste, including white paper, mixed paper, newspaper/magazines, aluminum, tin, glass, plastic, toner cartridges, and computer software, as well as seek to reuse office products. Information on how to reuse and recycle can be found in the GreenGuide on the PNNL Web pages at http://esp.pnl.gov:2080/esp/greenguide.

- Purchase products made of recycled material whenever economically practical, including paper, paper products, toner cartridges, binders, trash bags, and trash containers. 
Additionally, managers will integrate $\mathrm{P} 2$, resource conservation, and environmental impact considerations into planning and decision-making.

\subsubsection{Waste Generator}

The waste generator has the following responsibilities:

- Comply with all applicable environmental requirements.

- Look for opportunities to improve and streamline environmental management.

- Incorporate P2 techniques into those work activities that generate waste to minimize or eliminate the volume and/or toxicity associated with this waste. Generators should consider P2 techniques in the following hierarchical order: 1) source reduction, 2) reuse and recycling, and 3 ) treatment.

- Source reduction techniques include product substitution, inventory control, process changes, and other activities that prevent waste. Reuse and recycling techniques include chemical or material reuse or reclamation. Treatment techniques include neutralization, stabilization, decontamination, and compaction.

- Incorporate P2 into the project planning phase of all waste-generating activities to eliminate or minimize the generation of waste.

- Conduct P2 opportunity assessments (P2OAs) on waste-generating activities, with assistance from their ECRs or designee.

- Communicate P2 ideas, opportunities, and successes to the ECR or EC to enable sharing of ideas, facilitate reporting, promote positive Laboratory activities to regulators and customers, and track waste reduction and cost savings.

\subsubsection{Environmental Compliance Department (Internal P2 Program)}

EC is responsible for managing the PNNL P2 Program and maintaining P2 Program documentation. This includes reviewing the Plan annually and updating as appropriate, but no less than every three years. This will ensure that regulatory developments and programmatic changes by DOE Headquarters (HQ) and RL will be addressed in an ongoing manner. Generator guidance is also maintained by the EC organization. Environmental Compliance also maintains a staff of ECRs who act as liaisons between EC and waste generators.

Specific responsibilities of the EC P2 Program and P2 Coordinator are:

- Seek and establish senior management support for P2.

- Provide support to generators regarding the development and application of specific P2 technologies.

- Assist generators and ECRs to conduct P2OAs.

- Report P2 goals, progress, and accomplishments of the Laboratory to management, clients, DOE, and various regulatory agencies, as required.

- Prepare and issue a detailed annual report summarizing P2 progress and accomplishments during the previous year.

- Maintain the following P2 Program documentation in an auditable file:

- annual P2 goals

- evidence of separate and identifiable P2 budget 
- P2OA performance and implementation

- quarterly and annual P2 progress reports.

- Manage the Laboratory-wide office recycling program, including paper, cardboard, and other products.

- Communicate P2 information among staff and with others through verbal, written, and electronic media, to promote information exchange and expansion of $\mathrm{P} 2$ initiatives between organizations.

- Implement all other aspects of the PNNL P2 Program as required in this Plan (PNL-MA-822)

The ECR or designee has the following $\mathrm{P} 2$ responsibilities:

- Assist EC P2 staff in targeting waste-generating activities that are candidates for $\mathrm{P} 2 \mathrm{OAs}$ and assist EC $\mathrm{P} 2$ staff and generators in performing and completing P2OAs for these activities.

- Assist generators in implementing P2 initiatives.

- Communicate to EC P2, at least quarterly, the P2 progress and accomplishments of their generators.

\subsubsection{Waste Management Services Department}

Waste Management Services supports $\mathrm{P} 2$ by promoting it as the preferred methods to manage waste. If waste can be prevented before it requires treatment and disposal, then significant reductions in costs, employee exposure, and long-term risk can be realized. Waste Management Services has the following responsibilities:

- Track waste generation, monitor trends, and help EC P2, ECRs, and generators prioritize waste streams, in order to facilitate reporting and to help focus on the most costly and largest waste streams.

- Help set and meet P2 waste reduction goals and performance indicators.

- Maintain and promote a redistribution center in order to reduce potential waste materials, such as excess chemicals and equipment, from facility transition and routine activities at the Laboratory.

- Assist in hazardous and radioactive recycling programs at the Laboratory and Hanford site, including batteries, aerosols, excess chemicals, and other recyclable materials, both legally and cost effectively.

- Communicate P2 ideas, opportunities, and successes to the ECR or the EC to enable sharing of ideas, facilitate reporting, promote positive Laboratory activities to regulators and customers, and track waste reduction and cost savings.

\subsubsection{Environmental Technology Division P2 Product Line (External P2 Program)}

The part of the P2 Program dedicated to developing new P2 technologies and processes that can be applied within or outside the Laboratory is implemented through the ETD P2 Product Line. Their responsibilities include:

- developing new and innovative P2 technologies and programs

- marketing these new P2 initiatives both internally to PNNL and externally as a product line 
- interfacing with the EC and DOE Environmental Management (EM) programs to share information and expertise

- assisting generators with finding and implementing P2 solutions. 


\section{Program Elements}

\subsection{Program Coordination}

\subsubsection{Program Planning}

Program planning is an integral part of the PNNL P2 Program. PNL-MA-822 has been developed as a compliance document based on the Site Plan (DOE-RL, 1996). It demonstrates how PNNL will satisfy the requirements and guidance found in the Site Plan and describes the direction of the PNNL P2 Program regarding new P2 ideas and initiatives.

Additionally, P2 projects that are scheduled each year are subject to P2 Program coordination to ensure consistency of approach for PNNL P2 activities.

\subsubsection{Pollution Prevention Opportunity Assessments}

Pollution prevention opportunity assessments are a systematic approach to identifying methods for waste reduction. P2OAs are the preferred method of EPA and DOE for determining waste reduction initiatives. At PNNL, the P2 Program offers assistance in conducting P2OAs to the waste generators. This includes training, facilitation, and assistance in researching the opportunities found. Funding will be sought to enable researchers to conduct assessments.

Special attention will be given to helping generators complete a return on investment analysis and documenting that their P2 initiatives save money, in addition to the other environmental and worker benefits.

\subsection{Implementation and Integration}

Pollution prevention is an important part of all activities underway at the Laboratory. From the time of designing new facilities and processes through the disposal of final wastes, there are opportunities to integrate $\mathrm{P} 2$.

\subsubsection{Procurement}

Many opportunities for $\mathrm{P} 2$ are realized when procuring materials and supplies for Laboratory operations. Specific procurement activities underway at PNNL include the following:

- buying recycled products, such as paper, building materials, refurbished printer toner cartridges, and other items

- seeking to establish guidelines for procurement staff in the areas of recycled products and hazardous materials

- increasing staff awareness of using recycled materials

- complying with DOE affirmative procurement reporting requirements. 


\subsubsection{Inventory Management}

PNNL has developed the Chemical Management System (CMS) that allows research staff to identify chemical materials for redistribution. The CMS is used by PNNL staff to find particular chemicals. In an effort to make existing chemical inventories even more visible, the Pop Chem system was developed. The Pop Chem system receives data from CMS and is tied to the PNNL electronic telephone directory. Pop Chem and CMS are both promoted ways to exchange useful hazardous materials at PNNL.

PNNL also maintains a Chemical Redistribution Center (CRC) in order to reduce potential waste materials, such as excess chemicals and equipment, from facility transition and routine activities at the Laboratory. The CRC is used in addition to the CMS and PopChem to facilitate efficient use of hazardous materials that would have been excessed or disposed because they were no longer needed by the original owners.

PNNL also participates in the Office Exchange program, a networking project run by the site-wide contractor. This project publishes lists of office materials no longer needed to be used by others on the site.

\subsubsection{Research and Development}

The mission of PNNL is to conduct research and development (R\&D) to develop new scientific concepts and innovative technologies, P2 being an excellent area for development. Research and development of new P2 programs and technologies are managed by the ETD through the P2 Product Line. New innovations developed by any organization (including EC and WMS) with a goal of reducing waste and conserving resources will receive support and promotion from the P2 Product line. The innovations will potentially be "exported" to other sites and organizations.

Two kinds of $R \& D$ occur at PNNL relating to P2. The first is programmatic development, which is the development of new computer, training, or systems and management tools which help to prevent pollution or conserve resources. These programs can be used at the Laboratory and the Hanford site, then launched within DOE and externally to other interested organizations.

The second kind of $R \& D$ is technology development. This is the development of a new technology, scientific or engineering in origin, which reduces waste or conserves resources. Often the development of a new technology leads to forming partnerships with small manufacturing companies or the development from prototype to production.

\subsubsection{Resource Conservation}

The PNNL P2 Program considers energy and water conservation as vital elements of preventing pollution. The program participates with other resource conservation activities at PNNL and at Hanford to integrate energy conservation in the design of new facilities and provide strategies for water and other resource conservation during operations. Initiatives have included working with the Facilities and Operations Directorate to reduce water needs in landscaping and integrate energy efficient lighting into buildings occupied by PNNL. 


\subsubsection{Recycling}

A formal recycling program at PNNL currently recycles office paper, corrugated cardboard, mixed paper, newsprint, magazines, glass, plastic, tin and aluminum. Materials are collected by staff and placed in appropriate collection containers in various locations at the Laboratory. A vendor provides pick-up services for all recyclable commodities in exchange for a percentage of the current market value of office paper and corrugated cardboard. Revenues generated by the project are used to maintain the recycling program. The vendor provides monthly totals that are tracked.

Other recycling/reuse initiatives implemented by PNNL include the following:

- Electronic publications - PNNL converted a number of Laboratory-wide publications from paper to electronic distribution. Publications at PNNL continue to move towards electronic, rather than paper, versions.

- Electronic Signatures - Many signatures required for document authorization are now done electronically (including time cards), saving paper, reducing printing costs, and reducing employee time for data entry.

- Obsolete software recycling - PNNL is recycling obsolete software and documentation through a local contractor.

- Toner cartridge recycling - PNNL recycles toner cartridges through a central program.

- Maintenance Services recycling - The Maintenance Services Department recycles lead $\mathrm{acid} / \mathrm{gel}$ cell batteries, oil, spent solvent, wood and wood pallets, and steel drums.

Other materials will be recycled as possible.

\subsection{Awareness and Communication}

\subsubsection{Employee Training}

Pollution Prevention Opportunity Assessment training will be provided on request on a volunteer basis to all PNNL research staff who generate waste. The training will be subcontracted to the site-wide P2 organization. The P2OA training is divided into two main modules. The first module describes P2 concepts and how they relate to processes and wastes generated at PNNL. During the second module, the trainees conduct a P2OA on a waste generating activity that the trainees are familiar with from their own organization. The P2 opportunities generated from the training sessions are further researched, tracked, and assessed for implementation by the team.

\subsubsection{Employee Awareness and Incentives}

The P2 Program is responsible for keeping PNNL staff aware of current P2 projects and how they can participate in them. This includes providing information about P2OAs, office recycling, chemical exchange, affirmative procurement, and other projects. To communicate about these activities, the P2 Program uses PNNL and external publications, 
including the Greenie, EC Highlights, the Hanford Reach, and others. The P2 Program also promotes awareness through additional programs, including an Internet Home Page, an internal telephone Hotline, and cooperation with regional technical assistance resources.

PNNL staff's P2 achievements are recognized through newsletter articles and the Hanford Pollution Prevention Accomplishments Book (WHC, 1995). The PNNL incentive programs and Hanford site-wide programs are utilized to provide awards and recognition as well. Also, PNNL personnel are eligible for receiving awards from DOE at annual $\mathrm{P} 2$ conferences where individuals and groups are recognized for their outstanding P2 accomplishments. PNNL's P2 Program assists and encourages those who have conducted significant waste reduction to apply for this award and others. PNNL's P2 Program also publicizes and communicates PNNL employee accomplishments to DOE for recognition of those personnel and the Laboratory.

\subsubsection{External Outreach}

The P2 Program will participate in site-wide P2 meetings to facilitate the transfer of P2 information. In addition, the P2 Program will regularly attend offsite P2 seminars, workshops, and meetings for the same reason. Where applicable, PNNL will incorporate new ideas and initiatives gleaned from other sites, contractors, or private companies, and successes of the PNNL P2 Program will be shared with others.

\subsection{Performance Monitoring}

\subsubsection{Material Inventory Tracking}

The Westinghouse Hanford Company (WHC) developed Hazardous Material Inventory Database 2 (HMID2), a site-wide database used by PNNL to track hazardous materials and inventories. HMID2 is used to maintain current information on hazardous-chemical and hazardous-material inventories as defined by the EPCRA and the Occupational Safety and Health Administration Hazard Communications Standard. The overall architecture for HMID2 is based on a central host computer. Access to the host computer is through terminal emulation via the Hanford local area network. Except on special request, HMD2 does not currently provide an annual usage of material because materials are updated on a monthly basis and do not take into account daily usage changes.

The HMID2 contains the necessary information for determining priority hazardous materials. These priority materials will become the targets of $\mathrm{P} 2$ efforts.

\subsubsection{Waste Tracking}

PNNL developed the WGD to study trends in the various waste types generated. The WGD allows EC and EM P2 staff to choose the waste type, time frame, and the specific 
organization generating the waste. Waste Management Services is responsible for tracking waste generation trends through this database.

Another resource is the Solid Waste Information Tracking System, managed by the Project Hanford Management Contractors, which tracks radioactive waste sent to the Hanford site waste management for disposal. Waste tracking will be used to prioritize P2OAs and track progress on goals.

\subsubsection{Cost Accounting}

PNNL participated in the development of the DOE Waste Cost Avoidance Model. The Waste Cost Avoidance Model was designed for the purpose of identifying cost of waste generation, treatment, storage, and disposal across the DOE complex. This model established a total cost per quantity for each waste type and treatability group, and is used as a mechanism for evaluating P2 incentives by comparing cost savings and payback periods of the distinct initiatives. This model will be used when life-cycle cost numbers are needed to determine return on investment.

Disposal and associated labor costs for nonradioactive hazardous waste generated from DOE and DOE-related services contracts are funded through an ADS by PNNL's WMS Department, which operates the 305-B Permitted Storage Facility.

Radioactive waste disposal and associated labors costs are billed directly to the wastegenerating organization. The rates are based on the volume of waste generated and disposed and are set by the Hanford Operations and Engineering Contractor.

\subsubsection{P2OA and P2 Successes Tracking}

Documentation of P2OAs will be kept by EC as part of the P2 Program documentation. Follow-up will be made on the recommended opportunities as required. Other P2 successes will be tracked throughout the year and summarized annually in the annual report and the Annual Waste Minimization and Waste Generation Report.

\subsection{Compliance Reporting}

\subsubsection{Emergency Planning and Community Right-to-Know Act 311/312/313 Reports}

PNNL hazardous material usage and releases are reported to the EPA through the EPCRA 311,312 , and 313 reports. PNNL data entered into the WHC HMID2 Database are compiled by PNNL P2 staff at the end of each calendar year and included in the Hanford site EPCRA 312 and 313 reports. EPCRA 311 reporting consists of reviewing the monthly 
inventory report to ensure that PNNL is not exceeding the threshold planning quantity, as required by PNNL policy.

\subsubsection{Annual Report on Waste Generation and Waste Minimization (formerly SEN 37-92 Report)}

The PNNL P2 Program provides input to the site DOE Annual Report on Waste Generation and Waste Minimization Progress (formerly SEN-37-92) and is required by DOE Order 5400.1. This report requests waste generation data for low-level radioactive waste, lowlevel mixed waste, transuranic waste, transuranic mixed waste, hazardous waste (RCRA, State, TSCA), and sanitary waste. These data are then compared to previous years' data and trends are established for each waste stream. Increases and decreases in waste generation are explained in the report. The report also requires extensive reporting on recycling quantities and $\mathrm{P} 2$ success stories, including waste reduction quantities and return on investment calculations.

\subsubsection{Annual/Quarterly Reporting}

Annual and quarterly reports are completed in order to support many reports and requests required throughout the year. The annual report (submitted to the site-wide P2 Program) is used extensively to support the Annual Report on Waste Generation and Waste Minimization described above. The annual report also supports the biennial waste minimization report, which is the waste minimization portion of the Dangerous Waste Report, required by EPA through 40 CFR 262, "Standards Applicable to Generators of Hazardous Waste." Part of the information required in these biennial reports is a description of the efforts undertaken during the reporting period to reduce the volume and toxicity of waste generated.

Quarterly reports are used to track goals throughout the year at both a site-wide and PNNL level. They also ensure regular review of the P2 Program and gathering of P2 successes at the Laboratory on a periodic basis.

\subsubsection{Other Reporting}

The Washington State Department of Ecology requires waste generators to provide a report documenting the P2 Program at the generators' facility or facilities (WAC-173-307-Plans). This report must be updated annually in the form of a progress report.

A Presidential Executive Order places government facilities and their operating contractors on a schedule of compliance with toxic chemical reduction schedules such as those proposed in the voluntary EPA 33/50 Program. Laboratory research facilities are normally exempt from the 33/50 Program. However, DOE requires its research facilities to prepare 
an annual "Laboratory Exemption Report." This report details the use of priority chemicals such as those found in the EPCRA $312 / 313$ regulations

Additional reporting requirements include participation in the EPA Wastewise Program through Battelle Memorial Institute and other such programs.

\subsection{Funding}

No single source of funding has been adequate to support the PNNL P2 Program sufficiently to ensure compliance and realization of the PNNL P2 policy. Some funding comes from the EM Waste Minimization Division of DOE HQ and from DOE Energy Research, but these sources are subject to increasingly tight restraints. Supplemental funding is occasionally available to PNNL through DOE HQ, often in the form of funding for P2 projects with short turnaround and based on return on investment. PNNL will continue to compete for these funds, supported by the P2OA process.

Additionally, more independent funding is being pursued. This includes receiving recycling revenues and a surcharge on waste disposal costs recovered through a charge-back program. These funding sources will be used to support the generators in reducing their waste stream and to make the P2 Program more self-sufficient. 


\title{
Appendix 1 \\ Glossary
}

Disposal

Generator

Goal

Hazardous Substance

Hazardous Waste

Pollution Prevention (P2)
The final disposition of waste in a responsible and compliant manner that protects human health and the environment.

Each individual whose activities or processes produce waste.

A specific result toward which processes are directed.

Any material listed as a hazardous substance in the Emergency Planning and Community Right-To-Know Act and any further updates, and all ozone depleting compounds as defined by the Montreal Protocol of October 1987 and any further updates of the protocol.

Solid wastes that exhibit any of the characteristics of hazardous waste identified in 40 CFR 261, Subpart C (ignitable, corrosive, reactive, toxic) or listed in 40 CFR 261, Subpart D, "Lists of Hazardous Waste." Also includes dangerous waste as defined in WAC 173-303.

The use of materials, processes, or practices that reduce or eliminate the creation of pollutants or wastes at the source. It includes practices that reduce the use of hazardous and nonhazardous materials, energy, water, or other resources as well as those that protect natural resources through conservation or more efficient use.

\section{Pollution Prevention}

Program

A system of activities and projects which seeks to reduce all waste types and conserve natural resources through pollution prevention, according to the EPA hierarchy of source reduction, recycling, and finally treatment.

\section{Pollution Prevention Opportunity} Assessment (P2OA)

\begin{abstract}
A systematic approach that examines work activities and identifies and documents opportunities to minimize the generation of waste.
\end{abstract}


Recycling

Source Reduction

Treatment

Waste Reduction
Recycling techniques are characterized as use, reuse, and reclamation techniques (resource recovery). Use or reuse involves the return of a potential waste material either to the originating process as a substitute for an input material or to another process as an input material. Reclamation is the recovery of a useful or valuable material from a waste stream. Recycling allows potential waste materials to be put to a beneficial use instead of going to treatment, storage, or disposal.

The elimination or reduction of waste generation at the source. Source reduction activities and techniques include substitution of less hazardous materials, process optimization or modification, technology changes, administrative changes such as inventor control, and housekeeping practices such as waste segregation. Source reduction results in reducing or eliminating the amount of potential waste material existing from a process.

Technological processes that reduce the volume, toxicity, or mobility of waste. Examples include, but are not limited to, incineration, vitrification, neutralization, chemical extraction, physical separation, and solidification/stabilization technologies.

Reduction of the total amount of waste that is generated and disposed of through pollution prevention and treatment activities. 


\section{Appendix 2 \\ Applicable Pollution Prevention Regulations and Policies}

\begin{tabular}{|c|c|c|}
\hline Function & Driver & Effect \\
\hline $\begin{array}{l}\text { Federal Procurement } \\
\text { Guidelines }\end{array}$ & $\begin{array}{l}\text { Resource Conservation and } \\
\text { Recovery Act (RCRA) } \\
40 \text { CFR } 247\end{array}$ & $\begin{array}{l}\text { Encourages procurement of recovered materials } \\
\text { by the Federal Government }\end{array}$ \\
\hline $\begin{array}{l}\text { Generator Manifest } \\
\text { Certification }\end{array}$ & $\begin{array}{l}\text { RCRA } \\
40 \text { CFR 262, 264-265 }\end{array}$ & $\begin{array}{l}\text { Requires generator to put in place a hazardous } \\
\text { waste minimization program }\end{array}$ \\
\hline $\begin{array}{l}\text { Generator Biennial } \\
\text { Report Certification }\end{array}$ & $\begin{array}{l}\text { RCRA } \\
40 \text { CFR 262, 264-265 }\end{array}$ & $\begin{array}{l}\text { Requires generator to put in place a hazardous } \\
\text { waste minimization program }\end{array}$ \\
\hline $\begin{array}{l}\text { Part B Permit } \\
\text { Conditions }\end{array}$ & RCRA & $\begin{array}{l}\text { Requires generator to put in place a hazardous } \\
\text { waste minimization program }\end{array}$ \\
\hline $\begin{array}{l}\text { Liability Insurance } \\
\text { Requirements }\end{array}$ & RCRA & $\begin{array}{l}\text { Generator and facility owners and operators } \\
\text { reduce liability by reducing waste }\end{array}$ \\
\hline $\begin{array}{l}\text { Land Disposal } \\
\text { Restrictions }\end{array}$ & RCRA & Increases the cost of waste management \\
\hline $\begin{array}{l}\text { Exclusion to the } \\
\text { Toxicity } \\
\text { Characteristic }\end{array}$ & RCRA & $\begin{array}{l}\text { Minimizes chlorofluorocarbon (CFC) venting } \\
\text { and encourages recycling }\end{array}$ \\
\hline $\begin{array}{l}\text { Waiver of Sovereign } \\
\text { Immunity under } \\
\text { RCRA }\end{array}$ & $\begin{array}{l}\text { Federal Facilities Compliance } \\
\text { Act (FFCA) }\end{array}$ & $\begin{array}{l}\text { Government is subject to all RCRA } \\
\text { requirements with a } 3 \text { year delayed effective } \\
\text { date for mixed waste storage }\end{array}$ \\
\hline $\begin{array}{l}\text { Mixed Waste } \\
\text { Minimization } \\
\text { Reporting }\end{array}$ & FFCA & $\begin{array}{l}\text { National inventory of all mixed waste including } \\
\text { description of waste minimization actions }\end{array}$ \\
\hline $\begin{array}{l}\text { Toxic Release } \\
\text { Inventory Reporting }\end{array}$ & $\begin{array}{l}\text { Emergency Planning and } \\
\text { Community Right-to-Know } \\
\text { Act (EPCRA) }\end{array}$ & $\begin{array}{l}\text { Establish reporting requirements for the use, } \\
\text { storage, and onsite and offsite transfers of } \\
\text { hazardous and toxic chemicals }\end{array}$ \\
\hline National Policy & $\begin{array}{l}\text { Pollution Prevention Act } \\
\text { (PPA) }\end{array}$ & $\begin{array}{l}\text { Declared } \mathrm{P} 2 \text { as the first choice in environmental } \\
\text { management }\end{array}$ \\
\hline $\begin{array}{l}\text { Toxic Release } \\
\text { Inventory Reporting }\end{array}$ & PPA & $\begin{array}{l}\text { Expands SARA } 313 \text { reporting requirements to } \\
\text { include source reduction and recycling } \\
\text { information }\end{array}$ \\
\hline $\begin{array}{l}\text { Increased Reporting } \\
\text { Requirements }\end{array}$ & PPA & $\begin{array}{l}\text { Increases public access to information, } \\
\text { stimulating citizen enforcement and holds } \\
\text { industry to stricter standards }\end{array}$ \\
\hline
\end{tabular}




\begin{tabular}{|c|c|c|}
\hline Function & Driver & Effect \\
\hline $\begin{array}{l}\text { CERCLA Financial } \\
\text { Liability }\end{array}$ & $\begin{array}{l}\text { Comprehensive } \\
\text { Environmental Response, } \\
\text { Compensation and Liability } \\
\text { Act (CERCLA) }\end{array}$ & $\begin{array}{l}\text { Generators reduce future liability by reducing } \\
\text { waste }\end{array}$ \\
\hline $\begin{array}{l}\text { National Ambient Air } \\
\text { Quality Standards }\end{array}$ & Clean Air Act (CAA) & $\begin{array}{l}\text { Promotes cutting emissions of six hazardous air } \\
\text { pollutants }\end{array}$ \\
\hline $\begin{array}{l}\text { New Source } \\
\text { Performance } \\
\text { Standards }\end{array}$ & CAA & $\begin{array}{l}\text { New plants must conform to strict emission } \\
\text { requirements }\end{array}$ \\
\hline $\begin{array}{l}\text { Phased-In } \\
\text { Requirements }\end{array}$ & CAA & $\begin{array}{l}\text { Firms must meet new, more restrictive air } \\
\text { emission standards }\end{array}$ \\
\hline $\begin{array}{l}\text { Early Reductions } \\
\text { Program }\end{array}$ & CAA & $\begin{array}{l}\text { Compliance extensions for voluntary early } \\
\text { reductions of hazardous air pollutants }\end{array}$ \\
\hline $\begin{array}{l}\text { Maximum } \\
\text { Achievable Control } \\
\text { Technology (MACT) }\end{array}$ & CAA & $\begin{array}{l}\text { Directs EPA to consider } \mathrm{P} 2 \text { technologies when } \\
\text { selecting MACT }\end{array}$ \\
\hline $\begin{array}{l}\text { Clean Fuel Fleet } \\
\text { Program }\end{array}$ & $\mathrm{CAA}$ & $\begin{array}{l}\text { Requirement to meet clean-fuel fleet vehicle } \\
\text { emissions standards }\end{array}$ \\
\hline $\begin{array}{l}\text { Protection of } \\
\text { Stratospheric Ozone }\end{array}$ & $\mathrm{CAA}$ & $\begin{array}{l}\text { Phase-out of CFCs, halons, and carbon } \\
\text { tetrachloride by } 2000 \text {; limit on emissions of } \\
\text { ozone-depleting substances during the servicing, } \\
\text { use and disposal of equipment containing those } \\
\text { substances }\end{array}$ \\
\hline $\begin{array}{l}\text { Minimization } \\
\text { Certification }\end{array}$ & Clean Water Act (CWA) & $\begin{array}{l}\text { Requires a plan for industrial firms to diminish } \\
\text { the volume and toxicity of their hazardous } \\
\text { discharges }\end{array}$ \\
\hline $\begin{array}{l}\text { Radiation Protection } \\
\text { Programs }\end{array}$ & 10 CFR 835 & $\begin{array}{l}\text { Requires the establishment of goals and } \\
\text { performance indicators for the minimization of } \\
\text { radioactive waste. It also requires a waste } \\
\text { minimization program that will reduce the } \\
\text { generation of radioactive waste and spread of } \\
\text { contamination from Contamination, High } \\
\text { Contamination or Airborne Radioactivity Areas. }\end{array}$ \\
\hline $\begin{array}{l}\text { Significant New Use } \\
\text { Notification }\end{array}$ & $\begin{array}{l}\text { Toxic Substance Control Act } \\
\text { (TSCA) }\end{array}$ & $\begin{array}{l}\text { Makes firms legally responsible to EPA for } \\
\text { voluntary waste minimization commitment }\end{array}$ \\
\hline $\begin{array}{l}\text { Bans on Chemical } \\
\text { Substances }\end{array}$ & TSCA & $\begin{array}{l}\text { Eliminates feedstocks responsible for certain } \\
\text { waste streams }\end{array}$ \\
\hline $\begin{array}{l}\text { Handling and } \\
\text { Transportation } \\
\text { Requirements }\end{array}$ & $\begin{array}{l}\text { Hazardous Materials } \\
\text { Transportation Act (HMTA) }\end{array}$ & $\begin{array}{l}\text { Safety requirements raise costs of transporting } \\
\text { waste }\end{array}$ \\
\hline
\end{tabular}




\begin{tabular}{|c|c|c|}
\hline Function & Driver & Effect \\
\hline $\begin{array}{l}\text { Handling } \\
\text { Requirements }\end{array}$ & $\begin{array}{l}\text { Occupational Safety \& Health } \\
\text { Act (OSHA) }\end{array}$ & $\begin{array}{l}\text { Safety requirements raise costs of transporting } \\
\text { waste }\end{array}$ \\
\hline Environmental Taxes & $\begin{array}{l}\text { Revenue Reconciliation Act } \\
\text { (RRA) }\end{array}$ & Taxes on ozone-depleting chemicals \\
\hline $\begin{array}{l}\text { Research and } \\
\text { Development } \operatorname{Tax} \\
\text { Credits }\end{array}$ & Tax Reform Act (TRA) & $\begin{array}{l}\text { Provides for a tax credit for increasing } \\
\text { investment in research and development of } \\
\text { processes and products that reduce waste }\end{array}$ \\
\hline $\begin{array}{l}\text { Stormwater Pollution } \\
\text { Prevention Plan }\end{array}$ & CWA & $\begin{array}{l}\text { Requires that industrial stormwater discharge } \\
\text { facilities have an onsite P2 plan }\end{array}$ \\
\hline $\begin{array}{l}\text { General } \\
\text { Environmental } \\
\text { Protection Program }\end{array}$ & DOE 5400.1 & $\begin{array}{l}\text { Requires P2/WMin Plans, Annual Waste } \\
\text { Reduction Reports, and a Pollution Prevention } \\
\text { Awareness Program }\end{array}$ \\
\hline $\begin{array}{l}\text { Radioactive Waste } \\
\text { Management }\end{array}$ & DOE $5820.2 \mathrm{~A}$ & $\begin{array}{l}\text { Requires Waste Management Plans including } \\
\text { actions to minimize radioactive waste generation }\end{array}$ \\
\hline $\begin{array}{l}\text { Federal Compliance } \\
\text { with Right-to-Know } \\
\text { Laws and Pollution } \\
\text { Prevention } \\
\text { Requirements }\end{array}$ & $\begin{array}{l}\text { Executive Order (EO) } 12856 \\
\text { (August 3, 1993) }\end{array}$ & $\begin{array}{l}\text { Requires development of a P2 strategy and } \\
\text { agency development of a } 50 \text { percent reduction } \\
\text { goal in toxic chemicals releases by the of } 1999\end{array}$ \\
\hline $\begin{array}{l}\text { Federal Acquisition } \\
\text { Recycling, and Waste } \\
\text { Prevention }\end{array}$ & $\begin{array}{l}\text { EO } 12873 \text { (October 21, } \\
\text { 1993) }\end{array}$ & $\begin{array}{l}\text { Promotes reductions in waste generation } \\
\text { through recycling and the use of recycled and } \\
\text { energy efficient materials }\end{array}$ \\
\hline $\begin{array}{l}\text { Procurement } \\
\text { Requirements and } \\
\text { Policies for Ozone- } \\
\text { Depleting Substances }\end{array}$ & (EO) 12843 (April 21, 1993) & $\begin{array}{l}\text { Requires that Federal agencies minimize and } \\
\text { allow for phaseout of Class I and II ozone- } \\
\text { depleting substances }\end{array}$ \\
\hline $\begin{array}{l}\text { Federal Use of } \\
\text { Alternative Fueled } \\
\text { Vehicles }\end{array}$ & EO 12844 (April 21, 1993) & $\begin{array}{l}\text { Stimulates the availability, acquisition, and use } \\
\text { of alternatively-fueled vehicles for Federal } \\
\text { agencies }\end{array}$ \\
\hline $\begin{array}{l}\text { Requiring Agencies } \\
\text { to Purchase Energy } \\
\text { Efficient Computer } \\
\text { Equipment }\end{array}$ & EO 12845 (April 21, 1993) & $\begin{array}{l}\text { Requires that all acquisitions of microcomputers } \\
\text { meet "EPA Energy Star" requirements for } \\
\text { energy efficiency }\end{array}$ \\
\hline $\begin{array}{l}\text { Energy Efficiency } \\
\text { and Water } \\
\text { conservation at } \\
\text { federal facilities }\end{array}$ & EO 12902 (March 8, 1994) & $\begin{array}{l}\text { Requires to reduce energy and water } \\
\text { consumption from FY 1995-2005 according to } \\
\text { established baselines }\end{array}$ \\
\hline $\begin{array}{l}\text { Dangerous Waste } \\
\text { Regulations }\end{array}$ & WAC $173-303$ & $\begin{array}{l}\text { Requires generator certification that a waste } \\
\text { minimization program is in place for hazardous } \\
\text { waste }\end{array}$ \\
\hline
\end{tabular}




\begin{tabular}{|l|l|l|}
\hline \multicolumn{1}{|c|}{ Function } & \multicolumn{1}{|c|}{ Driver } & \multicolumn{1}{|c|}{ Effect } \\
\hline National Policy & Energy Policy Act & $\begin{array}{l}\text { Promotes energy conservation and efficiency } \\
\text { and promote renewable energy }\end{array}$ \\
\hline $\begin{array}{l}\text { Directs specific } \\
\text { percentage waste } \\
\text { reduction by waste } \\
\text { type }\end{array}$ & $\begin{array}{l}\text { Letter from Secretary } \\
\text { O'Leary dated May 3,1996 }\end{array}$ & $\begin{array}{l}\text { Requires site-specific P2 goals be established } \\
\text { and progress be tracked }\end{array}$ \\
\hline $\begin{array}{l}\text { Principal Guidance to } \\
\text { fully implement P2 } \\
\text { Program }\end{array}$ & $\begin{array}{l}\text { DOE-HQ 1996 Pollution } \\
\text { Prevention Program Plan }\end{array}$ & $\begin{array}{l}\text { Provides contractors with specific steps to meet } \\
\text { DOE's P2 commitments }\end{array}$ \\
\hline
\end{tabular}

